\title{
Cadmium and lead in seafood samples determined by solid phase extraction and graphite furnace atomic absorption spectrometry
}

\author{
Pipat Chooto $^{\mathrm{a}}$, Chalermpol Innuphat ${ }^{\mathrm{a}}$, Puchong Wararattananurak ${ }^{\mathrm{a}, *}$, Chaipat Lapinee ${ }^{\mathrm{b}}$ \\ a Department of Chemistry, Analytical Chemistry Division, Faculty of Science, \\ Prince of Songkla University, Hatyai, Songkhla 90112 Thailand \\ b Department of Chemistry, School of Science, University of Phayao, Muang Phayao, \\ Phayao 56000 Thailand \\ *Corresponding author, e-mail: puchong.w@psu.ac.th
}

Received 10 Aug 2014

Accepted 6 Feb 2015

\begin{abstract}
A sample preparation method has been developed to detect cadmium and lead in commercial frozen seafood samples. After being digested with concentrated $\mathrm{HNO}_{3}$ in a closed polypropylene vessel, the clear sample solution was separated and preconcentrated by solid phase extraction using octadecyl silica membrane discs modified with 8-hydroxyquinoline prior to determination by graphite furnace atomic absorption spectrometry (GFAAS). The preconcentration conditions including $\mathrm{pH}$, ligand quantity, eluent concentration, and volume were found to be effective with $10.0 \mathrm{mg}$ of 8-hydroxyquinoline in $2.0 \mathrm{ml}$ ethanol and $\mathrm{pH}$ 6.0. The retained cadmium and lead were efficiently eluted with $5.0 \mathrm{ml}$ of $1.0 \mathrm{M} \mathrm{HNO}_{3}$ and determined by GFAAS. The detection limits for cadmium and lead were $0.073 \mu \mathrm{g} / 1$ and $0.332 \mu \mathrm{g} / \mathrm{l}$, respectively. The proposed method was tested with the certified reference material, DORM2 (Dogfish muscle), with good agreement. The recoveries were found to be $100-103 \%(n=4)$ for Cd and $92-108 \%$ $(n=5)$ for $\mathrm{Pb}$ with relative standard deviation $(n=5)$ of $3 \%$ for $\mathrm{Cd}$ and $4 \%$ for $\mathrm{Pb}$. The extraction was found to be unaffected by coexisting ions. The method was applied satisfactorily to the seafood samples and trace levels of cadmium and lead were found.
\end{abstract}

KEYWORDS: preconcentration, 8-hydroxyquinoline, GFAAS

\section{INTRODUCTION}

Cadmium and lead are well recognized to be highly toxic elements to human being ${ }^{1,2}$. They are widely dispersed in the environment ${ }^{3-5}$, and the exposure to either element can produce adverse health effects due to their toxicity after accumulation in multiple organs in human body ${ }^{6}$. Most contaminations to human by cadmium and lead arise from food consumption ${ }^{7,8}$ hence the importance of their determinations in food samples ${ }^{9-11}$.

Graphite furnace atomic absorption spectrometry (GFAAS) is one of the most common techniques used for trace analysis of heavy metals as it is highly sensitivity, has low detection limits, and requires low sample volumes ${ }^{12}$. Direct determination of trace amounts of cadmium and lead in complicate matrices as food samples by GFAAS is usually difficult owing to interferences and insufficient detection power ${ }^{13-15}$. These difficulties however have been recently overcome by research on digestion ${ }^{16-18}$, preconcentration, and separation methods including solvent extraction, coprecipitation, ion exchange, and solid phase extraction procedures $^{19}$. Solvent extraction of different metal ions has been widely employed in chemistry and industry for many years. However, classical extraction methods are usually time consuming, labour-intensive and require relatively large volumes of high purity solvents. Additional concern is the disposal of used solvent which can create severe environmental problems. Much interest has been recently focused on replacing conventional solvent extraction methods in isolating environmental pollutants with solid phase extraction (SPE) techniques which are capable of selectively removing trace metal ions from complex matrices with minimal usage of organic solvent ${ }^{20}$. The application of SPE to metal ions is generally based on chelating matrices with current interest in designing macromolecular chelators with high sorption capacity, selectivity, and suitability ${ }^{21}$.

8-hydroxyquinoline ${ }^{22}$ (oxine) is a well-charac- 
terized and versatile chelating organic ligand which can form covalent compounds with a number of metal ions under controlled $\mathrm{pH}$. It has been immobilized on a variety of supports such as glass beads $^{23}$, silica gel ${ }^{24}$, polystyrene divinylbenzene ${ }^{25}$, silicon tube ${ }^{26}$, and ionic imprinted polymer ${ }^{27}$; thus becoming suitable to be used with sorbents in metal analysis.

Effective sorbents for solid phase extraction should possess unique characteristic including negligible swelling capacity to resist swelling and shrinking with changes in $\mathrm{pH}$ or solvent conditions, strong mechanical stability to withstand high flow rate and high chemical resistibility to endure harsh conditions. Octadecyl silica membrane discs are comprised of polytetrafluoroethylene (PTFE) polymer and chemically modified silica particles tightly bound in a web of micro-PTFE fibrils. They have a number of advantages as a solid support including chemical inertness, elevated resistibility, low friction coefficient and swelling resistance ${ }^{1}$.

This study develops a simple and rapid method for $\mathrm{Cd}$ and $\mathrm{Pb}$ determination in seafood samples by GFAAS by using 8-hydroxyquinoline modified octadecyl silica membrane disc as solid adsorbent for solid phase extraction to preconcentrate the metals. The developed method was optimized in terms of $\mathrm{pH}, 8$-hydroxyquinoline quantity, elution type and volume to obtain its analytical performance. The optimized method was then applied to seafood samples.

\section{MATERIALS AND METHODS}

\section{Apparatus}

A Perkin-Elmer Model A Analyst 800 atomic absorption spectrometer with Zeeman background correction equipped with transverse heated graphite atomizer and a Perkin-Elmer AS-800 autosampler was used to determine $\mathrm{Cd}$ and $\mathrm{Pb}$. Suction pump (BuCHI Laboratoriums-Technik AG, CH-9230 FLAWIL/SCHWEIZ, 300 W, 220 V AC, 50-60 Hz, Switzerland), Standard Millipore apparatus (47 mm diameter; Pyrex, USA) and 3 M Empore disc octadecyl silica membrane disc (47 mm diameter, thickness $0.50 \pm 0.05 \mathrm{~mm}$; St. Paul, MN) were used for solid phase extraction. Polypropylene vessels and water bath (S.V. Medico, Co. Ltd.) were used for sample digestion.

\section{Reagents and standard solutions}

Analytical reagent grade chemicals were employed for the preparation of all solutions. De-ionized water prepared from a Milli $\mathrm{Q}$ water purification system (Millipore, Bedford, MA, USA) was used throughout this work. Stock standard solutions (1000 mg/l) of $\mathrm{Cd}(\mathrm{II})$ and $\mathrm{Pb}(\mathrm{II})$ were obtained from the National Institute of standard and Technology (NIST) and diluted for obtaining reference and working solutions. Certified reference material (DORM-2) was obtained from the National Research Council Canada (NRC) for method verification. $\mathrm{Mg}\left(\mathrm{NO}_{3}\right)_{2}$ and $\mathrm{NH}_{4} \mathrm{H}_{2} \mathrm{PO}_{4}$ were used in the preparation of chemical modifiers.

\section{Sample collection and preparation}

Seafood samples were collected from frozen seafood companies in Trang, Pattani, and Songkhla provinces. The seafood samples were stored in polyethylene bags and were frozen at $-5^{\circ} \mathrm{C}$ until further processing. The frozen seafood samples were defrosted and homogenized. The homogenized tissue samples were dried to a constant weight at $80^{\circ} \mathrm{C}$ for $24 \mathrm{~h}$. The dried homogenized samples were collected in polyethylene bags until analysis.

\section{Sample digestion}

Three types of sample digestion including dry ashing, hot plate digestion and water bath digestion were experimented with the certified material. It was found that all three methods are equally efficient in terms of accuracy and precision (data not shown). The water bath digestion is preferable and recommended only because of its less time consuming and less contamination. A portion $(0.2 \mathrm{~g}$ dry weight) of sample was accurately weighed into polypropylene tube and $5.0 \mathrm{ml}$ of $\mathrm{HNO}_{3}$ were added. The polypropylene tube was covered with the spiral plastic cap and heated in water bath at $65^{\circ} \mathrm{C}$ for $3 \mathrm{~h}$. The solution was diluted to $25.0 \mathrm{ml}$ with de-ionized water.

\section{Solid phase extraction}

For solid phase extraction of samples under study, first octadecyl silica membrane disc (C18-Disk) was placed in the standard Millipore filtration apparatus and then washed with $10.0 \mathrm{ml}$ ethanol to remove all contaminants. After all the solvent has passed through the disc, it was dried by passing air for $5 \mathrm{~min}$. The disc conditioning was achieved by passing $10.0 \mathrm{ml}$ deionized water and $10.0 \mathrm{ml}$ ethanol onto the disc. A solution of $10.0 \mathrm{mg}$ of 8-hydroxyquinoline in $2.0 \mathrm{ml}$ ethanol was then introduced and was drawn slowly through the disc by vacuum. Finally, the disc was washed with $25.0 \mathrm{ml}$ deionized water and dried by passing air to obtain the modified 
disc ready for extraction. The sample solution was passed through the modified membrane disc and then the disc was dried by passing air through it for $5 \mathrm{~min}$. The analytes retained on the disc were eluted with $5.0 \mathrm{ml}$ of $1.0 \mathrm{M} \mathrm{HNO}_{3}$.

\section{RESULTS AND DISCUSSION}

\section{Optimization of solid phase extraction}

Both $\mathrm{Cd}(\mathrm{II})$ and $\mathrm{Pb}$ (II) ions are Lewis acid that exhibits a high tendency to form complexes with ligands containing $\mathrm{N}$ donor atoms with basic properties. The existence of $\mathrm{N}$ and $\mathrm{O}$ donating atoms in 8-hydroxyquinoline was expected to increase both the stability and selectivity of its complex over other metal ions, especially alkali and alkali earth cations. The experiment to investigate the quantitative retention of $\mathrm{Cd}(\mathrm{II})$ and $\mathrm{Pb}$ (II) ions by the octadecyl silica membrane disc modified by 8-hydroxyquinoline revealed that the discs were capable to retain both ions.

The optimized conditions for the extraction procedure were established by using $1.0 \mu \mathrm{g} / \mathrm{l} \mathrm{Cd}$ and $20.0 \mu \mathrm{g} / \mathrm{l} \mathrm{Pb}$ as the sample solutions. Parameters including $\mathrm{pH}$ of sample solutions, amount of 8-hydroxyquinoline, eluent solution types, and concentrations and eluent solution volumes were investigated as follows.

Most chelating ligands are conjugate bases of weak acids with a very strong affinity for hydrogen ions making the $\mathrm{pH}$ an important factor in the separation of metal ions by chelation, as it determines the value of the conditional stability constants of metal complexes on the surface of sorbent. The presence of $\mathrm{OH}$ and $\mathrm{NH}$ groups on the 8-hydroxyquinoline structures suggests that the extent of complexation is sensitive to $\mathrm{pH}$. The influence of the $\mathrm{pH}$ of aqueous samples on the recovery of $1.0 \mu \mathrm{g} / 1$ $\mathrm{Cd}$ and $20.0 \mu \mathrm{g} / \mathrm{l} \mathrm{Pb}$ from $25.0 \mathrm{ml}$ sample solutions was studied in the range of $\mathrm{pH} 1.0-8.0$ (adjusted by $0.1 \mathrm{M} \mathrm{HNO}_{3}$ or $0.1 \mathrm{M}$ ammonium hydroxide solutions). Values of $\mathrm{pH}$ higher than 8.0 were not investigated due to the possibility of hydrolysis of octadecyl silica which consequently decreases the active lifetime of the discs ${ }^{19}$. As shown in Fig. 1, the recoveries increase gradually for both metals up to $\mathrm{pH} 6$ and then decrease. This is because at low $\mathrm{pH}$ the $\mathrm{NH}$ group in 8-hydroxyquinoline is protonated whereas at high $\mathrm{pH}$ the deprotonation of the $\mathrm{OH}$ group occurs along with hydrolysis and precipitation reaction of both metals, resulting in less complexation of 8-hydroxyquinoline with Cd(II) and $\mathrm{Pb}(\mathrm{II})$. The best recovery of $\mathrm{Cd}(\mathrm{II})$ and $\mathrm{Pb}(\mathrm{II})$

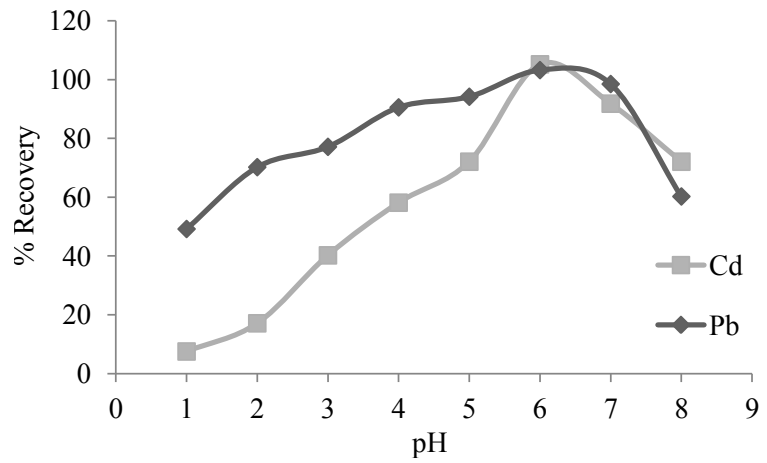

Fig. 1 Effect of pH on the recovery of $1.0 \mu \mathrm{g} / \mathrm{l} \mathrm{Cd}$ and $20.0 \mu \mathrm{g} / 1 \mathrm{~Pb}$ from $25.0 \mathrm{ml}$ sample solutions extracted by membrane disc modified with $10.0 \mathrm{mg}$ of 8-hydroxyquinoline.

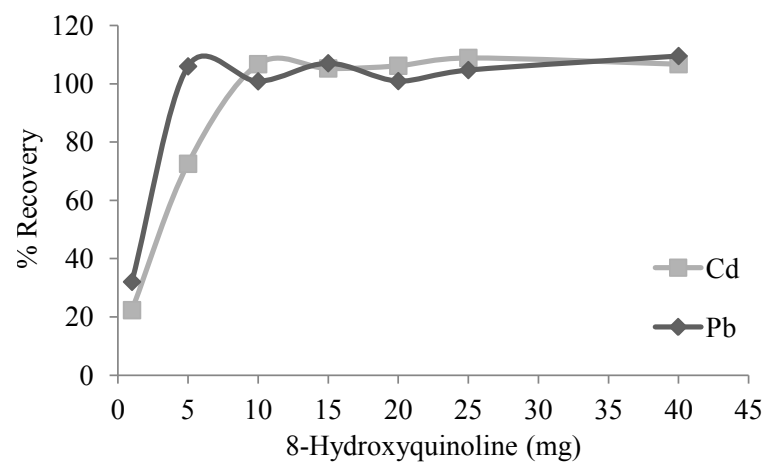

Fig. 2 Effect of 8-hydroxyquinoline quantity (in $2.0 \mathrm{ml}$ ethanol) on the extraction of $1.0 \mu \mathrm{g} / 1 \mathrm{Cd}$ (II) and $20.0 \mu \mathrm{g} / 1$ $\mathrm{Pb}$ (II) by octadecyl silica membrane discs from $25.0 \mathrm{ml}$ sample solution at $\mathrm{pH}$ 6.0.

ions was obtained at $\mathrm{pH} 6.0$ which was then adopted for further studies.

For the effect of 8-hydroxyquinoline amount on the quantitative extraction of $\mathrm{Cd}(\mathrm{II})$ and $\mathrm{Pb}$ (II) by the membrane disc, the investigation was conducted by varying the amount of 8-hydroxyquinoline from $1.0-40.0 \mathrm{mg}$ in $2.0 \mathrm{ml}$ ethanol for the extraction of $1.0 \mu \mathrm{g} / \mathrm{l} \mathrm{Cd}(\mathrm{II})$ and $20.0 \mu \mathrm{g} / \mathrm{l} \mathrm{Pb}$ (II) ions from $25.0 \mathrm{ml}$ sample solutions. Fig. 2 shows that the amounts of metals increased sharply to reach $100 \%$ recovery plateau at 8-hydroxyquinoline quantity of $10.0 \mathrm{mg}$, indicating quantitative extraction of both metals at this value and above. Hence $10 \mathrm{mg}$ was chosen.

Selecting a suitable eluent is vital for the analytical performance of solid phase extraction. Here, two eluents, $0.1-2.0 \mathrm{M} \mathrm{HNO}_{3}$ and $0.1-1.0 \mathrm{M}$ EDTA, were tested by investigating the recoveries of $1.0 \mu \mathrm{g} / 1 \mathrm{Cd}$ (II) and $20.0 \mu \mathrm{g} / 1 \mathrm{~Pb}$ (II) in $25.0 \mathrm{ml}$ 

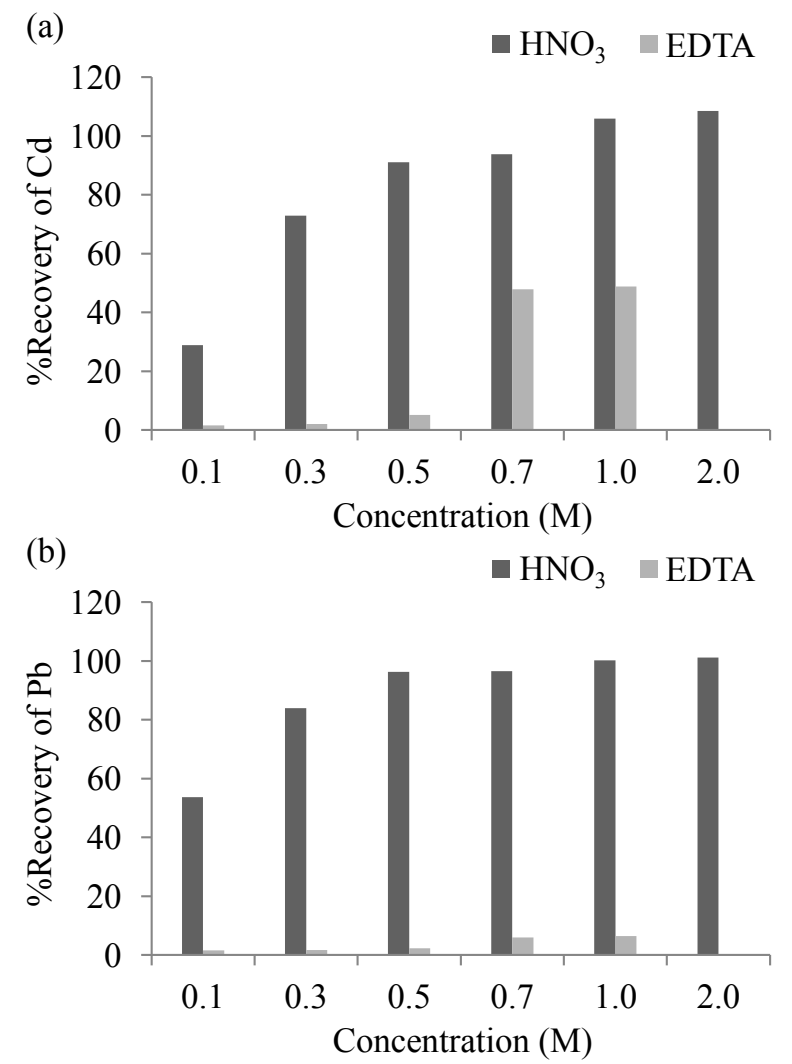

Fig. 3 Effect of the concentration of nitric acid and EDTA as eluents on the extraction of (a) $1.0 \mu \mathrm{g} / 1 \mathrm{Cd}$ (II) and (b) $20.0 \mu \mathrm{g} / \mathrm{l} \mathrm{Pb}$ (II) in $25.0 \mathrm{ml}$ of sample solution at $\mathrm{pH} 6.0$ using $10.0 \mathrm{mg}$ of 8-hydroxyquinoline in $2.0 \mathrm{ml}$ ethanol modified octadecyl silica membrane discs.

sample solution at $\mathrm{pH} 6.0$ with the extraction by $10.0 \mathrm{mg}$ of 8 -hydroxyquinoline in $2.0 \mathrm{ml}$ ethanol modified octadecyl silica membrane discs. It is evident from Fig. 3 that the recovery percentages for both metals are higher in the case of $\mathrm{HNO}_{3}$, reflecting its greater efficiency in quantitative elution of the adsorbed $\mathrm{Cd}(\mathrm{II})$ and $\mathrm{Pb}(\mathrm{II})$. Despite of the fact that EDTA is the chelating agent that can be complexed with various metal ions and was selected as an eluent to decomplex the adsorbed $\mathrm{Cd}$ and $\mathrm{Pb}$ complexed with 8-hydroxyquinoline on the extraction disc, the stability constants of EDTA complexes with $\mathrm{Cd}$ and $\mathrm{Pb}$ are less than those of 8-hydroxyquinoline. For 8-hydroxyquinoline (OX), its acid dissociation constants are $\mathrm{p} K_{\mathrm{a} 1}=$ 4.94 and $\mathrm{p} K_{\mathrm{a} 2}=9.66$; and its cumulative stability constants $(\beta)$ for $\mathrm{Pb}$ and $\mathrm{Cd}$ are $\log \beta\left(\mathrm{CdOX}^{+}\right)=$ 8.22, $\log \beta\left(\mathrm{CdOX}^{+}\right)=15.22, \log \beta\left(\mathrm{PbOX}^{+}\right)=10.03$ and $\log \beta\left(\mathrm{PbOX}_{2}\right)=17.34$ whereas for EDTA $\mathrm{p} K_{\mathrm{a} 1}=$ $2.00, \mathrm{p} K_{\mathrm{a} 2}=2.69, \mathrm{p} K_{\mathrm{a} 3}=6.18$, and $\mathrm{p} K_{\mathrm{a} 4}=10.15$;

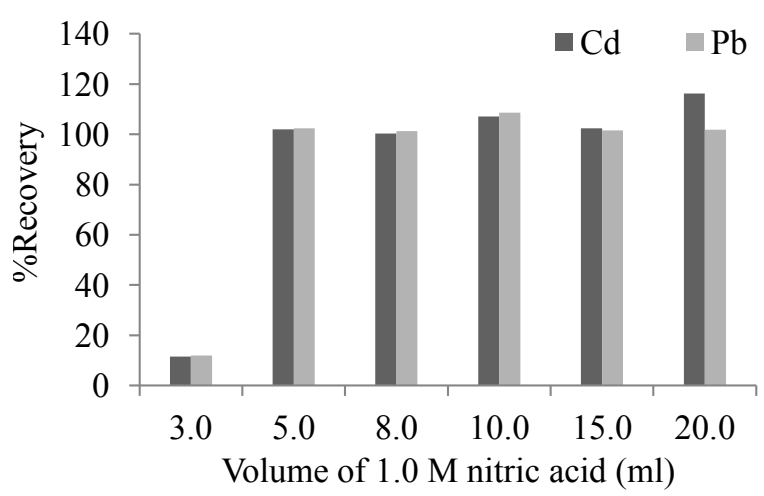

Fig. 4 Effect of volume of $1.0 \mathrm{M} \mathrm{HNO}_{3}$ on the elution of adsorbed $1.0 \mu \mathrm{g} / \mathrm{l} \mathrm{Cd(II)} \mathrm{and} 20.0 \mu \mathrm{g} / 1 \mathrm{~Pb}$ (II) on the modified membrane discs.

Table 1 The optimum conditions for solid phase extraction using 8-hydroxyquinoline modified octadecyl silica membrane disc.

\begin{tabular}{lc}
\hline Parameters & Optimum conditions \\
\hline $\mathrm{pH}$ & 6.0 \\
8-hydroxyquinoline & $10.0 \mathrm{mg}$ \\
Eluent type & $\mathrm{HNO}_{3}$ \\
Eluent concentration & $1.0 \mathrm{M}$ \\
Eluent volume & $5.0 \mathrm{ml}$ \\
\hline
\end{tabular}

$\log \beta\left(\mathrm{CdH}(\mathrm{EDTA})^{-}\right)=9.07, \log \beta\left(\mathrm{PbH}(\mathrm{EDTA})^{-}\right)=$ 9.68, and $\log \beta\left(\mathrm{PbH}_{2}(\mathrm{EDTA})\right)=6.22^{26}$; hence it is not strong enough to decomplex the adsorbed metals. The optimum eluent for $\mathrm{Cd}$ and $\mathrm{Pb}$ extraction was therefore $1.0 \mathrm{M} \mathrm{HNO}_{3}$.

The next parameter is the eluent volume. Generally, the higher the eluent volume, the greater the extracted amount of metals. However, the volume of eluent should be just enough to quantitatively extract the metals. In our case, the percentages of recoveries were increased but not beyond the eluent volume of $5.0 \mathrm{ml}$ (Fig. 4). Hence $5.0 \mathrm{ml}$ of $1.0 \mathrm{M}$ $\mathrm{HNO}_{3}$ was selected for further studies.

The optimum conditions for $\mathrm{Cd}$ and $\mathrm{Pb}$ preconcentrations using 8-hydroxyquinoline modified octadecyl silica membrane discs are summarized in Table 1.

\section{Analytical performance of the proposed method}

The efficiency of the solid phase extraction by using octadecyl silica membrane discs modified by 8-hydroxyquinoline under the optimum conditions was investigated in terms of maximum capacity of the modified membrane disc to retain the analytes, effect of coexist ions interference, detection limit, 
as well as accuracy and precision. The maximum capacity of the modified membrane disc is defined as the maximum amount of $\mathrm{Cd}$ and $\mathrm{Pb}$ which can be absorbed on the modified membrane disc with $10.0 \mathrm{mg}$ 8-hydroxyquinoline in $2.0 \mathrm{ml}$ ethanol. The investigation was carried out by passing $25.0 \mathrm{ml}$ of $1000 \mu \mathrm{g} / \mathrm{l} \mathrm{Cd}$ and $\mathrm{Pb}$ at $\mathrm{pH} 6.0$ and the retained metal ions in the elution solution were determined by GFAAS. The maximum capacity of the disc obtained from three measurements was $28.7 \pm 1.4 \mu \mathrm{g} / 1$ and $109.1 \pm 2.1 \mu \mathrm{g} / 1$ of $\mathrm{Cd}$ and $\mathrm{Pb}$ on the modified membrane discs, respectively.

In order to investigate the interference of coexisting ions in the determination of $\mathrm{Cd}(\mathrm{II})$ and $\mathrm{Pb}(\mathrm{II})$ ions, $25.0 \mathrm{ml}$ aqueous solution containing $1.0 \mu \mathrm{g} / 1$ $\mathrm{Cd}(\mathrm{II})$ and $20.0 \mu \mathrm{g} / \mathrm{l} \mathrm{Pb}(\mathrm{II})$ and interfering ions were experimented by solid phase extraction and GFAAS. The absorbance of the $\mathrm{Cd}$ and $\mathrm{Pb}$ in the presence of other ions were compared with that in the solution without interference. It was found that the absorbances with and without coexisting ions including $\mathrm{Na}^{+}, \mathrm{K}^{+}, \mathrm{Ca}^{2+}, \mathrm{Mg}^{2+}, \mathrm{Zn}^{2+}$, and $\mathrm{Cl}^{-}$were 0.1202 and 0.1219 for $\mathrm{Cd}$; 0.0972 and 0.1062 for $\mathrm{Pb}$. Interference was therefore insignificant according to $t$-test at $95 \%$ confidence level with relative standard deviation (RSD) $\leqslant 5(n=3)$, $t_{\mathrm{cal}(n=6)}=0.50$ for $\mathrm{Cd}, t_{\mathrm{cal}(n=6)}=1.81$ for $\mathrm{Pb}$, and $t_{\text {crit(at } 95 \%)}=2.78$ for both Cd and Pb.

The detection limits of the proposed method for $\mathrm{Cd}$ and $\mathrm{Pb}$ determination were studied by measuring ten replicates of the blank solution. The detection limits of $\mathrm{Cd}$ and $\mathrm{Pb}$ from $3 \sigma / \mathrm{m}$, where $\sigma$ is the standard deviation of blank signal and $\mathrm{m}$ is the slope of the calibration graph, were 0.073 and $0.332 \mu \mathrm{g} / \mathrm{l}$, respectively.

The accuracy of the developed method was evaluated by analysis of certified reference material (DORM-2). With the certified concentrations of $0.043 \pm 0.008 \mu \mathrm{g} / \mathrm{g}$ for $\mathrm{Cd}$ and $0.065 \pm 0.007 \mu \mathrm{g} / \mathrm{g}$ for $\mathrm{Pb}$, the determined concentrations were $0.045 \pm 0.001 \mu \mathrm{g} / \mathrm{g}$ for $\mathrm{Cd}(\mathrm{RSD}=2.45)$ and $0.071 \pm 0.003 \mu \mathrm{g} / \mathrm{g}$ for $\mathrm{Pb}(\mathrm{RSD}=4.49)$ which are in good agreement according to $t$-test (RSD $\leqslant 5$ $(n=3), t_{\mathrm{cal}(n=3)}=2.75$ for $\mathrm{Cd}, t_{\mathrm{cal}(n=3)}=2.66$ for $\mathrm{Pb}$, and $t_{\text {crit(at } 95 \%)}=4.30$ for both $\mathrm{Cd}$ and $\left.\mathrm{Pb}\right)$. The precision of the proposed method was investigated by measuring of five replicates of $1.0 \mu \mathrm{g} / \mathrm{l} \mathrm{Cd}(\mathrm{II})$ and $20.0 \mu \mathrm{g} / 1 \mathrm{~Pb}$ (II) sample solution in terms of RSD of the absorbance $(n=5)$ which was found to be $3 \%$ for $\mathrm{Cd}$ and $4 \%$ for $\mathrm{Pb}$. The recovery for Cd was found to be $100-103 \%(n=4)$ and for $\mathrm{Pb}$ $92-108 \%(n=5)$. The analytical performance of the investigated method is summarized in Table 2.
Table 2 Analytical performance of the proposed method with solid phase extraction using $10.0 \mathrm{mg}$ 8-hydroxyquinoline modified octadecyl silica membrane discs.

\begin{tabular}{lcc}
\hline Parameters & $\mathrm{Cd}$ & $\mathrm{Pb}$ \\
\hline Maximum capacity $(\mu \mathrm{g} / \mathrm{l})$ & $30.7 \pm 3.8$ & $169 \pm 11$ \\
Coexisting ion interference & None & None \\
Detection limits $(\mu \mathrm{g} / \mathrm{l})$ & 0.073 & 0.332 \\
Precision $(\% \mathrm{RSD})^{\mathrm{a}}$ & 3.09 & 3.80 \\
Recovery $(\%)^{\mathrm{a}}$ & $100-103^{\mathrm{b}}$ & $92-108^{\mathrm{a}}$ \\
\hline
\end{tabular}

${ }^{\mathrm{a}}(n=5)$

${ }^{\mathrm{b}}(n=4)$

Table 3 The contamination of $\mathrm{Cd}$ and $\mathrm{Pb}$ in frozen tuna fish from the seafood companies in the South of Thailand.

\begin{tabular}{cccc}
\hline Company & Lot No. & \multicolumn{2}{c}{ Contamination level $(\mu \mathrm{g} / \mathrm{g})$} \\
\cline { 2 - 4 } & & $\mathrm{Cd}$ & $\mathrm{Pb}$ \\
\hline 1 & 1 & $0.015 \pm 0.001$ & $0.129 \pm 0.022$ \\
& 2 & $0.016 \pm 0.002$ & $0.105 \pm 0.026$ \\
& 3 & $0.015 \pm 0.005$ & $0.115 \pm 0.009$ \\
& 4 & $0.009 \pm 0.002$ & $0.032 \pm 0.003$ \\
& 1 & $0.006 \pm 0.001$ & $0.033 \pm 0.004$ \\
& 2 & $0.001 \pm 0.000$ & $0.020 \pm 0.013$ \\
& 3 & $0.007 \pm 0.001$ & $0.108 \pm 0.019$ \\
& 4 & $0.008 \pm 0.002$ & $0.041 \pm 0.022$ \\
& 5 & $0.008 \pm 0.001$ & $0.009 \pm 0.001$ \\
& 1 & $0.003 \pm 0.001$ & $0.046 \pm 0.016$ \\
& 2 & $0.006 \pm 0.001$ & $0.032 \pm 0.010$ \\
& 3 & $0.005 \pm 0.000$ & $0.044 \pm 0.007$ \\
4 & 4 & $0.002 \pm 0.001$ & $0.041 \pm 0.008$ \\
& 5 & $0.005 \pm 0.001$ & $0.061 \pm 0.007$ \\
& 1 & $0.012 \pm 0.000$ & $0.022 \pm 0.008$ \\
& 2 & $0.006 \pm 0.002$ & $0.015 \pm 0.001$ \\
& 3 & $0.008 \pm 0.001$ & $0.057 \pm 0.018$ \\
& 4 & $0.003 \pm 0.001$ & $0.035 \pm 0.016$ \\
& 5 & $0.007 \pm 0.000$ & $0.079 \pm 0.006$ \\
\hline
\end{tabular}

\section{Determination of $\mathrm{Cd}$ and $\mathrm{Pb}$ in seafood samples}

The proposed method was found to be satisfactorily applicable for $\mathrm{Cd}$ and $\mathrm{Pb}$ determination in a variety of seafood samples from the frozen seafood companies in Trang, Pattani, and Songkhla provinces of Thailand with the results as shown in Tables 3 and 4, for example, 0.001-0.016 $\mu \mathrm{g} / \mathrm{g}$ Cd(II) and $0.009-0.129 \mu \mathrm{g} / \mathrm{g} \mathrm{Pb}(\mathrm{II})$ in the case of tuna fish, reflecting that the concentrations of cadmium and lead in those seafood samples were at trace level.

\section{CONCLUSIONS}

The proposed method demonstrated a maximum capacity of $30.7 \pm 3.8 \mu \mathrm{g} / 1$ for cadmium and 
Table 4 The contamination of $\mathrm{Cd}$ and $\mathrm{Pb}$ in frozen squid, cuttlefish, octopus, and prawns from seafood companies in Southern Thailand.

\begin{tabular}{lccc}
\hline Sample & Lot No. & \multicolumn{2}{c}{ Contamination level $(\mu \mathrm{g} / \mathrm{g})$} \\
\cline { 2 - 4 } & & $\mathrm{Cd}$ & $\mathrm{Pb}$ \\
\hline Squid & 1 & $0.004 \pm 0.000$ & $0.165 \pm 0.010$ \\
& 2 & $0.003 \pm 0.000$ & $0.035 \pm 0.005$ \\
& 3 & $0.006 \pm 0.000$ & $0.089 \pm 0.009$ \\
& 4 & $0.007 \pm 0.000$ & $0.018 \pm 0.002$ \\
& 5 & $0.001 \pm 0.001$ & $0.037 \pm 0.018$ \\
& 6 & $0.009 \pm 0.000$ & $0.006 \pm 0.001$ \\
Cuttlefish & 7 & $0.002 \pm 0.000$ & $0.005 \pm 0.000$ \\
& 1 & $0.003 \pm 0.000$ & $0.003 \pm 0.000$ \\
Octopus & 2 & $0.004 \pm 0.000$ & $0.005 \pm 0.000$ \\
& 3 & $0.003 \pm 0.000$ & $0.003 \pm 0.000$ \\
& 1 & $0.019 \pm 0.001$ & $0.002 \pm 0.001$ \\
& 2 & $0.028 \pm 0.000$ & $0.005 \pm 0.001$ \\
Prawn & 3 & $0.049 \pm 0.002$ & $0.018 \pm 0.003$ \\
& 4 & $0.036 \pm 0.000$ & $0.012 \pm 0.002$ \\
& 1 & $0.002 \pm 0.000$ & $0.013 \pm 0.004$ \\
& 2 & $0.004 \pm 0.000$ & $0.005 \pm 0.001$ \\
& 3 & $0.002 \pm 0.000$ & $0.013 \pm 0.000$ \\
& 4 & $0.002 \pm 0.000$ & $0.007 \pm 0.001$ \\
& 5 & $0.002 \pm 0.000$ & $0.022 \pm 0.001$ \\
& 6 & $0.003 \pm 0.000$ & $0.025 \pm 0.004$ \\
\hline
\end{tabular}

$169 \pm 11 \mu \mathrm{g} / \mathrm{l}$ for lead and detection limits of $0.073 \mu \mathrm{g} / \mathrm{l}$ for cadmium and $0.332 \mu \mathrm{g} / \mathrm{l}$ for lead with percentage of recoveries of $100-103 \%$ for Cd and $92-108 \%$ for $\mathrm{Pb}$ and RSD $(n=5)$ of $3 \%$ for $\mathrm{Cd}$ and $4 \%$ for $\mathrm{Pb}$. When applied to seafood samples in Thailand, the method revealed trace level of both metals. The developed method is recommended as another potential candidate for routine industrial seafood analysis.

Acknowledgements: The authors would like to thank PERCH (Postgraduate Education and Research Programme in Chemistry), Department of Chemistry, Faculty of Science, Prince of Songkla University, and Graduate School, Prince of Songkla University for financial support.

\section{REFERENCES}

1. Wang ZH, Zhang ZP, Wang ZP, Liu LW, Yan XP (2004) Acrylic acid grafted polytetrafluoroehylene fiber as new packing for flow injection on-line microcolumn preconcentration coupled with flame atomic absorption spectrometry for determination of lead and cadmium in environmental and biological samples. Anal Chim Acta 514, 151-7.

2. Storelli MM, Barone G (2013) Toxic metals (Hg, Pb, and $\mathrm{Cd}$ ) in commercially important demersal fish from Mediterranean Sea: contamination levels and dietary exposure assessment. J Food Sci 72, 362-6.

3. Ashraf MA, Akib S, Jamil Maah M, Yusoff I, Balkhair KS (2013) Cesium-137: Radio-chemistry, fate and transport, remediation and future concerns. Crit Rev Environ Sci Tech 44, 1740-93.

4. Ashraf MA, Jamil Maah M, Yusoff I (2012) Removal of lead from synthetic solutions by protonated teleosts biomass. E J Chem 9, 345-53.

5. Abu Bakar AF, Yusoff I, Fatt NT, Othman F, Ashraf MA (2013) Arsenic, zinc, and aluminium removal from gold mine wastewater effluents and accumulation by submerged aquatic plants (Cabomba piauhyensis, Egeria densa, and Hydrilla verticillata). Biomed Res Int 2013, ID 890803.

6. Correia PRM, Oliveira E, Oliveira PV (2000) Simultaneous determination of $\mathrm{Cd}$ and $\mathrm{Pb}$ in foodstuffs by electrothermal atomic absorption spectrometry. Anal Chim Acta 405, 205-11.

7. Lemos VA, Guardia M, Ferreira SLC (2002) An online system for preconcentration and determination of lead in wine samples by FAAS. Talanta 58, 475-80.

8. Pastorelli AA, Baldini M, Stacchini P, Baldini G, Morelli S, Sagratella E, Zaza S, Ciardullo S (2012) Human exposure to lead, cadmium and mercury through fish and seafood product consumption in Italy: a pilot evaluation. Food Addit Contam A 29, 1913-21.

9. Ashraf MA, Maah MJ, Yusoff I (2011) Assessment of heavy metals in the fish samples of mined out ponds Bestari Jaya, Peninsular Malaysia. Proc Indian Natl Sci Acad 77, 57-67.

10. Ashraf MA, Maah MJ, Yusoff I (2012) Bioaccumulation of heavy metals in fish species collected from former tin mining catchment. Int $J$ Environ Res 6, 209-18.

11. Yusoff I, Alias Y, Yusof M, Ashraf MA (2013) Assessment of pollutants migration at Ampar Tenang landfill site, Selangor, Malaysia. Sci Asia 39, 392-409.

12. Tang Y, Chen B, Mo S (1996) Separation and preconcentration of ultra-trace lead in biological organisms and its determination by graphite furnace atomic absorption spectrometry. Talanta 43, 761-76.

13. Saracoglu S, Divrikli U, Soylak M, Elci L (2002) Determination of copper, iron, lead, cadmium, cobalt and nickel by atomic absorption spectrometry in baking powder and baking soda samples after preconcentration and separation. J Food Drug Anal 10, 188-94.

14. Yan XP, Adam F (1997) Electrothermal atomic absorption spectrometry for in vivo monitoring. $J$ Anal Atom Spectrom 12, 459-64.

15. Olmedo P, Pla A, Hernández AF, Barbier F, Ayouni L, Gil F (2013) Determination of toxic elements (mercury, cadmium, lead, tin and arsenic) in fish and shellfish samples. Risk assessment for the consumers. Environ Int 59, 63-72. 
16. Jalbani N, Soylak M (2015) Ligandless ultrasonicassisted and ionic liquid-based dispersive liquidliquid microextraction of copper, nickel and lead in different food samples. Food Chem 167, 433-7.

17. López-García I, Briceño M, Vicente-Martínez Y, Hernández-Córdoba M (2015) Rapid screening of water soluble arsenic species in edible oils using dispersive liquid-liquid microextraction. Food Chem 167, 396-401.

18. Psoma AK, Pasias IN, Rousis NI, Barkonikos KA, Thomaidis NS (2014) Development, validation and accreditation of a method for the determination of $\mathrm{Pb}, \mathrm{Cd}, \mathrm{Cu}$ and $\mathrm{As}$ in seafood and fish feed samples. Food Chem 151, 72-8.

19. Soylak M, Divrikli U, Elci L, Dogan M (2002) Preconcentration of $\mathrm{Cr}(\mathrm{II}), \mathrm{Co}(\mathrm{II}), \mathrm{Cu}(\mathrm{II}), \mathrm{Fe}(\mathrm{II})$ and $\mathrm{Pb}(\mathrm{II})$ as calmagites on cellulose nitrate membrane filter prior to their flame atomic absorption spectrometric determinations. Talanta 56, 565-70.

20. Hashemi OR, Kargar MR, Raoufi F, Moghimi A, Aghabozorg H, Ganjali MR (2001) Separation and preconcentration of trace amounts of lead on octadecyl silica membrane disks modified with a new S-containing Schiff's base and its determination by flame atomic absorption spectrometry. Microchem $J$ 69, 1-6.

21. Gurnani V, Singh AK, Venkataramni B (2003) Cellulose functionalized with 8-hydroxyquinoline: new method of synthesis and applications as a solid phase extractant in the determination of metal ions by flame atomic absorption spectrometry. Anal Chim Acta 485, 221-32.

22. Willie SN, Tekgul H, Sturgeon RE (1998) Immobilization of 8-hydroxyquinoline onto silicone tubing for the determination of trace elements in seawater using flow injection ICP-MS. Talanta 47, 439-45.

23. Leyden DE, Luttrell GH, Sloan AE, DeAngelis NJ (1976) Characterization and application of silylated substrates for the preconcentration of cations. Anal Chim Acta 84, 97-108.

24. Daih B, Huang H (1992) Determination of trace elements in sea water by flow-injection anodic stripping voltammetry preceded by immobilized quinolin-8ol silica gel preconcentration. Anal Chim Acta 258, 245-52.

25. Resing JA, Mottl MJ (1992) Determination of manganese in seawater using flow injection analysis with on-line preconcentration and spectrophotometric detection. Anal Chem 64, 2682-7.

26. Abollino O, Aceto M, Sarzanini C, Mentasti E (2000) The retention of metal species by different solid sorbents mechanisms for heavy metal speciation by sequential three column uptake. Anal Chim Acta 411, 223-37.

27. Barciela-Alonso MC, Plata-García V, Rouco-López A, Moreda-Piñeiro A, Bermejo-Barrera P (2014) Ionic imprinted polymer based solid phase extraction for cadmium and lead pre-concentration/determination in seafood. Microchem $J$ 114, 106-10. 